\title{
TITLE:
}

\section{ON SOME ALCYONARIANS FROM THE WEST-PACIFIC ISLANDS (PALAU, PONAPE AND BONINS)}

\author{
$\operatorname{AUTHOR}(\mathrm{S})$ : \\ Utinomi, Huzio
}

\section{CITATION:}

Utinomi, Huzio. ON SOME ALCYONARIANS FROM THE WEST-PACIFIC ISLANDS (PALAU, PONAPE AND BONINS). PUBLICATIONS OF THE SETO MARINE BIOLOGICAL LABORATORY 1956, 5(2): 221-242

ISSUE DATE:

1956-06-30

URL:

http://hdl.handle.net/2433/174555

RIGHT: 


\title{
ON SOME ALCYONARIANS FROM THE WEST-PACIFIC ISLANDS (PALAU, PONAPE AND BONINS) ${ }^{13}$
}

\author{
HUZIo UTINOMI
}

Seto Marine Biological Laboratory, Sirahama

With 9 Text-figures

The Alcyonarian fauna of the tropical West-Pacific region, covering the large area of Micronesia in a wide sense, has previouly been scarcely investigated, though a few records concerning the Alcyonacea were noted by MAY (1900) and KüKENTHAL (1903, 1905).

During my stay at Koror of the Palau Islands as a research associate of the Palao Tropical Biological Station from June 1934 to February 1935 to study the marine fauna inhabiting the coral reef, I was much impressed by the abundance of fleshy Alcyonaceans, covering extensive areas of the reef edges or seaward slopes and the marked fewness of Gorgonaceans with an only exception of a few species of Melithaea (=Melitodes) and Junceella. Owing to having other objects, however, my shorecollecting could not be extended to the Alcyonaria at that time. Fortunately enough, some of the unstudied materials from Micronesia, mainly collected in the Palau Islands, which may be only available as the Micronesia collection made by Japanese zoologists in the pre-war time, were kindly placed at my disposal for study.

All the material dealt with in this paper is from the following three sources. The Museum of the Zoological Institute of Kyoto University at Kyoto possesses 12 samples which were collected by Syô Takahashi, then Professor of Hiroshima Higher Normal School, at Palau Islands during a short stay between March 5-30, 1915. The Museum of the Zoological Institute of Tokyo University at Tokyo has a very few samples from Bonin (Ogasawara) Islands collected by Sadamori Hirota and Ryûtarô SEKIGUCHI between February 10 to April 22, 1894, and one from Ponape Island. In the Museum of the Seto Marine Biological Laboratory at Sirahama, there is a small collection, most of which were made by Toshihiko Yamanouchi in 1937 during the survey of Iwayama Bay of Koror Island, containing my own made in 1934.

To all the gentlemen in charge of the collections of these Institutions and to Dr. Shinkishi Hatal, then Director of the Palao Tropical Biological Station, I wish to express my hearty thanks.

1) Contributions from the Seto Marine Biological Laboratory, No. 279.

Publ. Seto Mar. Biol. Lab., V (2), 1956. (Article 13) 
For the locality names used in the following text, GRESSITT's gazetteer (1954) is followed here for convenience, but only partially synonyms previously used by Japanese are also put in parentheses. The abbreviations of the sources of the material are as follows :

Z. I. K.…....Zoological Institute, Kyoto University, Kyoto.

Z. I. T..........Zoological Institute, Tokyo University, Tokyo.

S. M. B. L. … Seto Marine Biological Laboratory, Sirahama.

\section{LIST OF SPECIES}

Stolonifera

Clavularia inflata SchenK

Ponape

Pachyclavularia violacea (QuoY et GAIMARD)

Bonins

Tubipora musica Linnaeus

Palau

Telestacea

Telesto trichostemma (DANA)

Palau

Alcyonacea

Heteroxenia pinnata RoxAs

Palau

Microspicularia krempfi (HICKSON)

Palau

$M$. sphaerophora (EHRENBERG)

Bonins

Sinularia polydactyla (EHRENBERG)

Palau

S. flexibilis (QUOY et GAIMARD)

Palau

S. gardineri (PRATT)

Palau

Sarcophyton acutangulum (MARENZELLER)

Palau

$S$, digitatum MOSER

Palau

S. glaucum (Quoy et GAIMARD)

Palau

S. tenuispiculatum THOMSON et DEAN

Palau

S. trocheliophorum MARENZELLER

Palau

Lobophytum crebriplicatum MARENZELLER

Capnella fungiformis KüKENTHAL

Palau, Bonins

Paralemnalia thyrsoides (EHRENBERG)

Palau

Palau

Nephthea chabrolii Audouin

Palau

Dendronephthya köllikeri KÜKENTHAL

Palau

D. palaoensis UTINomi

Palau

D. spinulosa (GRAY)

Palau

Coenothecalia

Heliopora coerulea (PALlAS)

Palau

Gorgonacea

Melithaea ochracea (LiNNAEUS)

Palau

M. squamata (NuTTING)

Palau 
Isis hippuris LINNAEUS

Plexaura flava NutTing

Junceella squamata TOEPLITZ

Pennatulacea

Pennatula fimbriata HERKLots
Palau

Palau

Palau

Palau

\section{STOLONIFERA}

\section{Family Clavulariidae HicksoN \\ Clavularia inflata SCHENK}

Clavularia inflata UтіNomi, 1953, p. 150, text-figs. 1-2, pl. 8, figs. 1-2.

Material examined: Adult colonies attached to an ascidian Polycarpa aurata (Quoy et GaIMARD), Ponape Island, date and collector unknown (Z. I. T.).

Distribution: Philippines (Luzon), East Indies, Great Barrier Reef (Low Isles), Formosa, Southern Japan (Tokara Islands).

\section{Pachyclavularia violacea (QUOY et GAIMARD)}

Pachyclavularia violacea GoHAR, 1940, p. 20.

Clavularia violacea RoxAs, 1933a, p. 59.

Pachyclavularia erecta Roule, 1908, p. 165, 3 figs.; MOLANDER, 1929, p. 24; THOMSON \& DEAN, 1931, p. 19, pl. 2, figs. 4, 8 \& 9 ; pl. 5, figs. $6,7 \& 9$; pl. 16 , figs. 1 \& 2 ; MACFADYEN, 1936, p. 25.

Material examined: One colony growing on a stone, Titizima, Bonin Islands, April 1894, coll. S. Hirota and R. SeKiguchi (Z. I. T.).

This extraordinary beautiful stoloniferan of bright reddish violet color, which was named by Roule (1908) as Pachyclavularia erecta n. g. et sp., is so far little known, although it may not be less common on the coral reefs in the tropical West-Pacific region. Its peculiar structure was fully described by THOMson and DEAN (1931) and the systematic position of the genus Pachyclavularia has already been discussed by MoLANDER (1929, p. 24), Macfadyen (1936, p. 23) and Gohar (1940, p. 17). The last-named author, who examined the type specimen of Clavularia violacea Quoy et GArmarD preserved in the Muséum d'Histoire Naturelle, Paris, concludes that the two species, violacea and erecta, are synonymous. I am also of the same opinion on this point, but does not follow him in rejecting it from the Tubiporidae.

Distribution: Santa Cruz Islands (Vanikoro), East Indies, Philippines (Luzon), Great Barrier Reef (Wishart's Reef), Formosa (Garanbi). 


\title{
Family Tubiporidae GraY
}

\section{Tubipora musica LinNAEUS}

Material examined: dry specimens, Outer reef of Palau Islands, coll. H. UTinomi (1934) and T. Tokioka (1940) (S. M. B. L.).

Distribution: Widespread in the tropical Indo-Westpacific.

\section{TELESTACEA}

\author{
Family Telestidae H. Milne-Edwards
}

\section{Telesto trichostemma (DANA)}

(Fig. 1)

Telesto trichostemma LAACKMANN, 1908, p. 77 ; KÜKENTHAL, 1911, p. 326, text-figs. 42-44, pl. 21, fig. 14.

Material examined: 3 fragments, Ngarengelngael Passage (Geruherugairu Suidô) in Iwayama Bay, Koror Island, 1937, coll. T.YAMANouchI (S. M. B. L.).
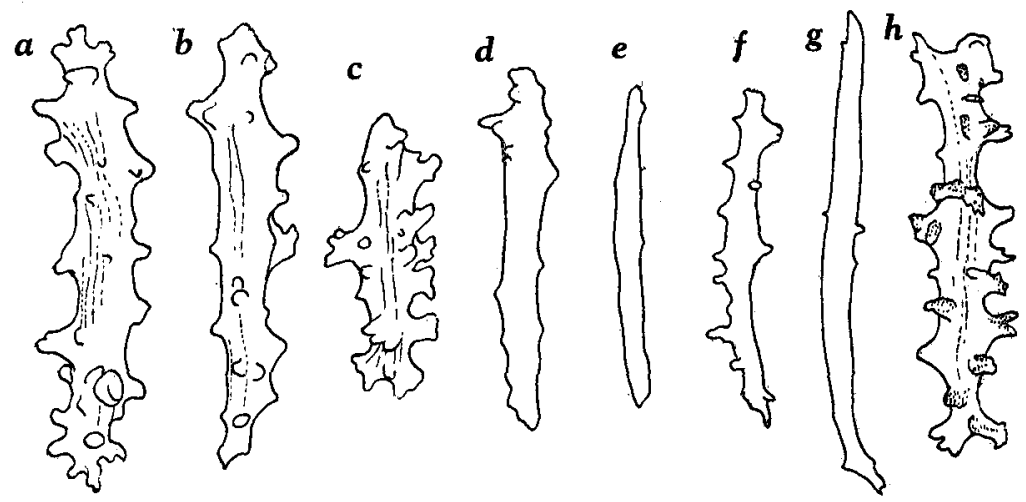

Fig. 1. Telesto trichostema (DANA).

Spicules of : $a-e$, polyps; $f-h$, stem (All $\times 150)$

The specimens are fragmental, but all covered together by an encrusting siliceous sponge. The stem is slender, undivided, $23-33 \mathrm{~mm}$ in length and $0.8-1.2 \mathrm{~mm}$ in diameter; each may be branches issuing from a single colony. A few lateral polyps arise at an angle of about $40^{\circ}$. The height of polyps is up to $3 \mathrm{~mm}$ and the diameter about $1 \mathrm{~mm}$. The coenenchyme is soft in texture and dirty white in color. Spicules are tuberculated rods, becoming more slender and smooth towards the tip of polyps, about $0.18 \times 0.018 \mathrm{~mm} \sim 0.3 \times 0.07 \mathrm{~mm}$. They are thickly disposed longitudinally on polyps and irregularly on stems. And they are interlocked with one another by virtue of their processes and occasionally fused together on stems. 
Distribution: Fiji Islands, Torres Strait, Aru Islands, Maldive Islands.

Hickson (1921, p. 369) recorded this species from Uraga Channel off Tokyo Bay, in $40-200$ fathoms. From his brief note without figures, however, it is difficult to justify his identification on the Japanese specimen, since previous records are all from shallow sea of the tropical waters.

\section{ALCYONACEA}

\section{Family Xeniidae VERRILL}

\section{Heteroxenia pinnata RoxAs}

Heteroxenia elizabethae Hiro, 1937b, p. 237 (not KÖLliKer's elisabethae).

H. pinnata Roxas, 1933a, p. 102, pl. 4, fig. 9; UTINOMI, 1950, p. 86, fig. 2 b.

Material examined: 8 specimens, reef flat of Ulebsehel (Oropusyakaru) Island, Palau Islands, 1934, coll. H. Utinomi (S. M. B. L.). 3 specimens, the same place, 1934, coll. H. UTINomi (Z. I. K.).

As I have already mentioned, this dimorphic xeniid is luxuriant on the reef flat only facing the outer lagoon around Ulebsehel Island, and the rhythmical movement of pulsating tentacles is easily observed in the field.

Distribution: Philippines (Mindoro Island), Palau Islands.

\section{Family Alcyoniidae VerRILL}

Microspicularia krempfi (Hickson)

(Fig. 2, $a-k$ )

Alcyonium Krempfi Hickson, 1919, p. 411, figs. 1-2.

Lobularia Krempfi Tixier-Durivault, 1948, p. 96, figs. 88-93.

Material examined: 3 colonies, Koror Island, 1937, coll. T. Yamanouchi (S. M. B. L.).

The capitulum is cerebriform, round to oval in outline, measuring $4.5 \times 3.2 \mathrm{~cm}$, $5 \times 3 \mathrm{~cm}$ and $7 \times 4.5 \mathrm{~cm}$ in spread respectively and about $2 \mathrm{~cm}$ in height. Capitular lobes are rather large, round to polygonal 8 to $18 \mathrm{~mm}$ in longest diameter and 5 to $15 \mathrm{~mm}$ in height. Polyps are uniformly arranged on lobes, $0.7-0.9 \mathrm{~mm}$ in diameter and completely retractile. Tentacles, about $0.5 \mathrm{~mm}$ long, long-stalked, with usually 3-paired pinnules widened proximally, and bear on the back of median rachis tiny spicules, which are sometimes lacking. These spicules are finger-biscuit-like to elongate, smooth discs, from $0.025 \times 0.01 \mathrm{~mm}$ to $0.037 \times 0.011 \mathrm{~mm}$, or feebly warted rods with a slight median constriction, from $0.052 \times 0.023 \mathrm{~mm}$ to $0.06 \times 0.034 \mathrm{~mm}$. In cortex and coenenchyme of both the lobes and stalk are contained larger capstans with large rounded warts, which are wider than high, about $0.056 \times 0.037 \mathrm{~mm} \sim 0.1 \times 0.075 \mathrm{~mm}$. 
Their shape is almost similar, but those in the basal coenenchyme are somewhat larger than in the lobular cortex.

Distribution: Nhatrang Bay (Vietnam), Seychelles, Madagascar.
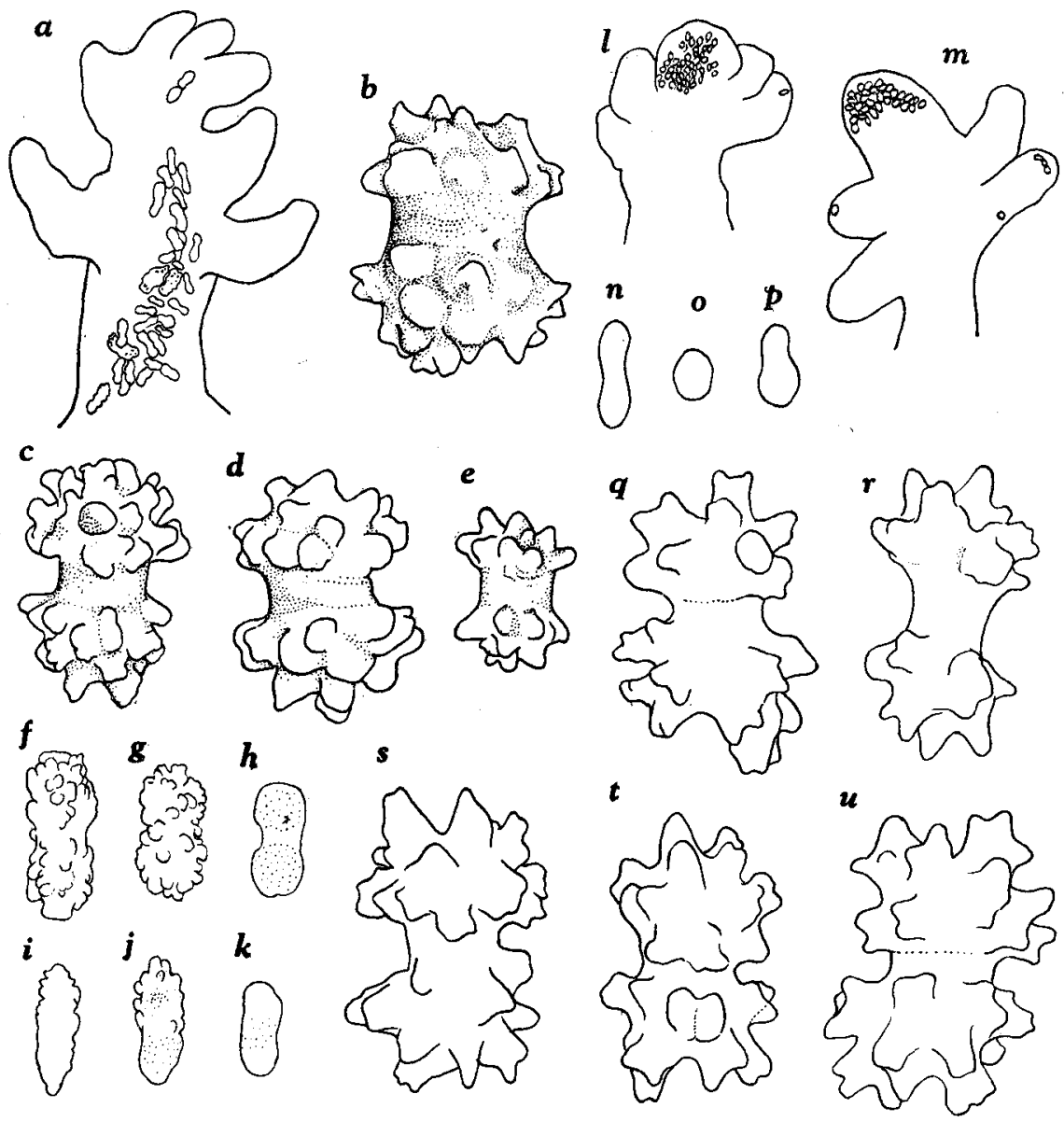

Fig. 2. $a-k$, Microspicularia krempfi (HICKSON): $a$, tentacle bearing spicules on axis alone; $b$, coenenchymal spicule of base; $c-e$, cortical spicules of lobes; $f-k$, spicules of tentacles. $l-u$, Microspicularia sphaerophora (EHRENBERG) $: l-m$, tentacles bearing spicules at ends; $n-p$, spicules of tentacles; $q-r$, coenenchymal spicules of lobes; $s-t$, cortical spicules of lobes; $u$, cortical spicule of base.

$(a, l$ and $m, \times 80$; the rest, $\times 335$ )

\section{Microspicularia sphaerophora (EHRENBERG)}

(Fig. 2, $l-u$ )

Alcyonium sphärophorum KLUNZINGER, 1877, p. 22, pl. 1, fig. 1 .

Lobularia sphaerophora Tixier-Durivault, 1948, p. 29, figs. 15-19. 
Material examined: 2 colonies, Anizima, Bonin (Ogasawara) Islands, April 1894, coll. S. Hirota and R. Sekiguchi (Z. I. T.).

Both specimens are compressed, rounded oval in outline and cerebriform in upper surface. They measure respectively as follows:

$47 \times 39 \mathrm{~mm}$ in spread; $15 \mathrm{~mm}$ high.

$50 \times 35 \mathrm{~mm}$ in spread; $20 \mathrm{~mm}$ high.

Lobes rounded, $6 \times 5 \mathrm{~mm}$ to $12 \times 8 \mathrm{~mm}$ wide and $10 \mathrm{~mm}$ high. Zooids minute, $0.5-0.7 \mathrm{~mm}$ in diameter and count about 7 to a length of $5 \mathrm{~mm}$. Cortical spicules are rather uniform: they are tuberculated capstans with a narrow median waist, about $0.065 \times 0.035 \mathrm{~mm} \sim 0.11 \times 0.065 \mathrm{~mm}$; the warts at both ends are broad and usually bifid at tip. In coenenchyme of lobes there are similarly shaped spicules, though with a narrower and longer median waist and roundly tipped warts. A cluster of fingerbiscuit-shaped spicules, about $0.019-0.03 \mathrm{~mm}$ long, occur at the expanded axial end of tentacles and a few on two-paired pinnules.

Distribution: Red Sea, Madagascar, Zanzibar, Seychelles, Tahiti.

\section{Sinularia polydactyla (EHRENBERG)}

Material examined : 3 specimens, $5-11.5 \mathrm{~cm}$ in length, Palau Islands, March 1915, coll. S. TAKAHASHI (Z. I. K.).

This well-known sinulariid coral is very luxuriant around the reef edge of the Palau Islands, decreasing to the inner part of Iwayama Bay in abundance, and grows to a large size on the outer reef.

Distribution: Widespread in the Indo-Westpacific.

\section{Sinularia flexibilis (QUOY et GAIMARD)}

Material examined: A small specimen, $13 \mathrm{~cm}$ long, Palau Islands, March 1915, coll. S. TAKAHASHI (Z.I.K.).

The specimen shows a typical appearance of this remarkable species, bearing a number of long, flexible branches on the top of the stout cylindrical stalk with a height of $8 \mathrm{~cm}$ and a diameter of $2.8 \mathrm{~cm}$. Terminal branches are finger-like up to $15 \mathrm{~mm}$ long, with a maximum diameter of about $3 \mathrm{~mm}$ and completely devoid of spicules. Cortical spicules of the stalk are irregular small clubs, 0.07 to $0.13 \mathrm{~mm}$ long, while in the interior occur heavy spindles with low rounded warts, though not thickly set, about $0.5 \times 0.08 \mathrm{~mm} \sim 1.5 \times 0.18 \mathrm{~mm}$. The stalk spindles are rather small compared with previous descriptions of this species as well as the other sinulariids.

Distribution: Vanikoro, Fiji, Samoa, Great Barrier Reef, East Indies, Vietnam, Philippines. 


\section{Sinularia gardineri (PRATT)}

(Fig. 3, $a-m$ )

Sinularia gardineri UTINOMI, 1954a, p. 50, fig. 6.

Material examined: 2 specimens, Ngarengelngael Passage in Iwayama Bay, Koror Islands, 1937, coll. T. Yamanouchi (S. M. B. L.).

Two flat colonies, both with a spread of $7 \times 4 \mathrm{~cm}$ and a height of $2-3 \mathrm{~cm}$, agree well with this species in the manner of growth and in the distinctive spiculation.
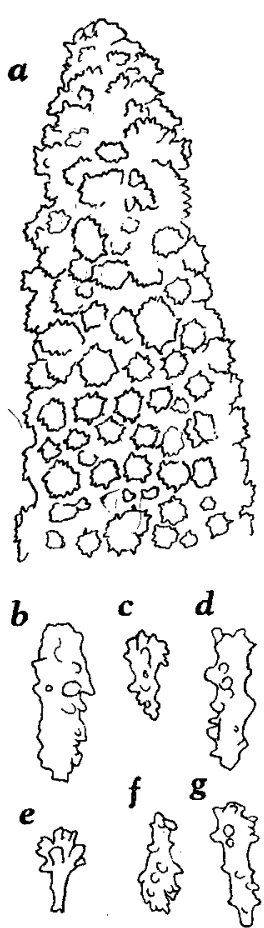
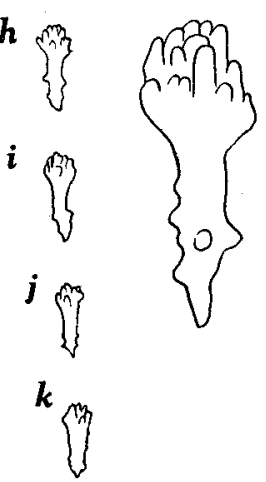

$\boldsymbol{m}$

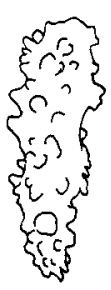

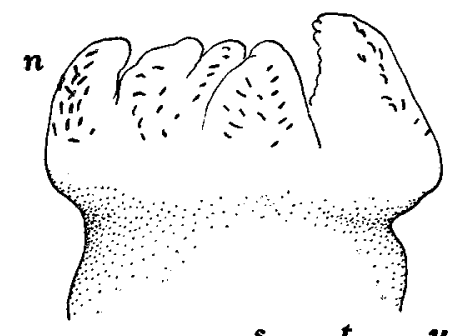

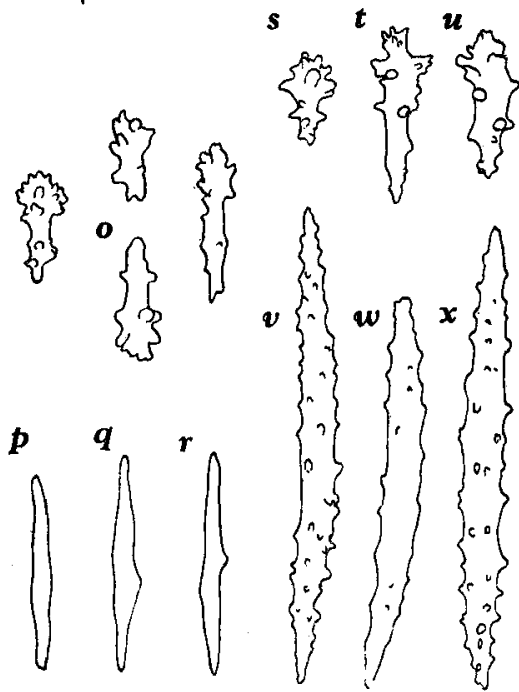

Fig. 3. $a-m$, Sinularia gardineri (PRATT): $a$, part of coenenchymal spindle ; $b-g$, warty rods of stalk cortex; $h-l$, cortical clubs of stalk; $m$, warty rod of disc cortex. $n-x$, Sarcophyton digitatum MOSER: $n$, autozooid; $o$, cortical spicules of disc; $p-r$, coenenchymal spicules of disc ; $s-u$, cortical spicules of stalk; $v-x$, coenenchymal spicules of stalk.

$(n, \times 35 ; l, \times 415 ;$ the rest, $\times 100)$

The lobes scattered on the upper surface, about $5 \mathrm{~mm}$ apart from one another, are short, digitate in form, about 4-12 mm long and bluntly tipped, not subdivided. Cortical clubs about $0.08-0.11 \mathrm{~mm}$ long and $0.037 \mathrm{~mm}$ wide, with a knotty mass of warts, no central wart called as such being present at the tip of head. In addition, warty 
rods up to $0.3 \mathrm{~mm}$ long occasionally occur. Coenenchymal spicules are large, heavily warted spindles up to $3 \mathrm{~mm}$ long.

Distribution: Red Sea, Ceylon, Maldives, East Indies, Great Barrier Reef, middle Japan (Kii coast).

\section{Sarcophyton acutangulum (MARENZELLER)}

Material examined: A fragment $3.5 \mathrm{~cm}$ long, Koror Island, Palau Islands, 1937, coll. T. Yamanouchi (S. M. B. L.).

Distribution: Widespread in the Indo-Westpacific, as far north as Kii coast of middle Japan.

\section{Sarcophyton digitatum MOSER}

(Fig. 3, $n-x$ )

Sarcophyton digitatum Roxas, 1933b, p. 380, pl. 1, fig. 8; MACFAdyen, 1936, p. 41.

Material examined: 2 colonies, 7-9 cm long, Palau Islands, March 1915, coll. S. TAKahashi (Z.I.K.).

In both specimens, the stalk is long, cylindrical and the margin of the capitulum is regularly folded into 5 high folds, arising to a height of $4 \mathrm{~cm}$, and projects far out of the stalk. Autozooids are very numerous, so thickly set on disc that only one siphonozooid between two autozooids. They are, when extended, $4 \mathrm{~mm}$ long and 0.6$0.8 \mathrm{~mm}$ in diameter. The spiculation of the disc and stalk is almost similar. Cortical spicules are warty rods or clubs, about $0.09 \times 0.037 \mathrm{~mm} \sim 0.18 \times 0.056 \mathrm{~mm}$; the head of clubs is only irregularly knobby. Coenenchymal spicules are slender spindles feebly warted to wholly smooth, ranging from $0.18 \times 0.015 \mathrm{~mm}$ to $0.28 \times 0.028 \mathrm{~mm}$ in smooth form and from $0.45 \times 0.035 \mathrm{~mm}$ to $0.7 \times 0.04 \mathrm{~mm}$ in warted form. On aboral surface of the autozooids are seen smaller rod-like spicules.

Distribution: Philippines, Seychelles, Great Barrier Reef.

\section{Sarcophyton glaucum (QuOX et GAIMARD)}

Material examined: A young, unfolded colony, $3 \mathrm{~cm}$ high and $2.4 \mathrm{~cm}$ wide, Palau Islands, March 1915, coll. S. TAKAhASHI (Z. I. K.).

Distribution: Widespread in the Indo-Westpacific.

\section{Sarcophyton tenuispiculatum THOMSON et DEAN}

(Fig. 4)

Sarcophytum tenuispiculatum THOMSON and DEAN, 1931, p. 64, pl. 22, fig. 6 .

Material examined: One specimen, Ngarengelngael Passage in Iwayama Bay, Koror Island, 1937, coll. T. Yamanouchi (S. M. B. L.). 
A single specimen, dull brown in color, with the margin of disc convoluted into about 10 high and low folds, has a maximum disc diameter of $11 \mathrm{~cm}$ and a stalk $10 \mathrm{~cm}$ in height.

The margin of the disc is not thick, about 4-6 $\mathrm{mm}$ in thickness and projects only slightly over the slightly broadened apical portion of the stalk. Autozooids are $0.3 \mathrm{~mm}$ in diameter, about $1-1.5 \mathrm{~mm}$ apart, and there are about $9-11$ autozooids to a centimeter

- at the margin. Siphonozooids are clear to the naked eye and only 2 between two autozooids at the margin, though $2-3$ in the center of the disc.

The spiculation is very characteristic, differentiating into the following four regions.

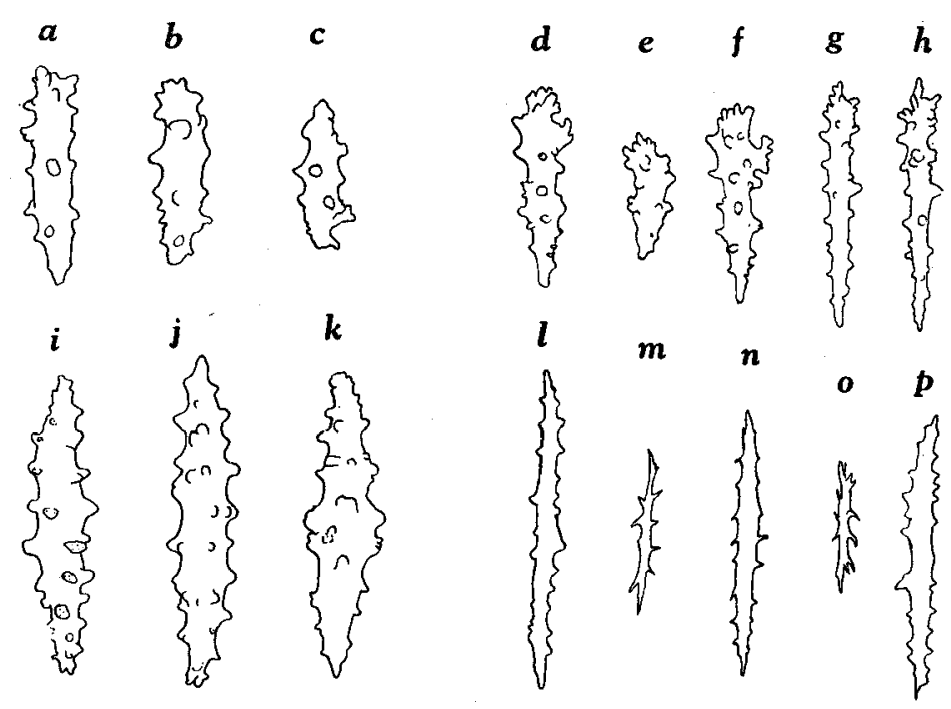

Fig. 4. Sarcophyton tenuispiculatum THOMSON et DEAN.

Spicules of : $a-c$, stalk cortex; $d-h$, disc cortex; $i-k$, stalk interior ; $l-p$, disc interior.

$($ All $\times 100)$

(a) In the stalk cortex are mainly short warty rods which may be derived from the spindle type : $0.12 \times 0.035 \mathrm{~mm}, 0.17 \times 0.07 \mathrm{~mm}, 0.23 \times 0.07 \mathrm{~mm}$.

(b) In the stalk interior are all ordinary spindles with somewhat distant zoned warts : $0.25 \times 0.05 \mathrm{~mm}, 0.3 \times 0.07 \mathrm{~mm}, 0.35 \times 0.05 \mathrm{~mm}$.

(c) In the disc cortex are deformed spindles or pseudoclubs: $0.12 \times 0.05 \mathrm{~mm}$, $0.16 \times 0.05 \mathrm{~mm}, 0.26 \times 0.04 \mathrm{~mm}$.

(d) In the disc interior are delicate, slender spindles with relatively few, sharply pointed warts and pointed at both ends: $0.12 \times 0.02 \mathrm{~mm}, 0.18 \times 0.02 \mathrm{~mm}$, $0.35 \times 0.03 \mathrm{~mm}$.

Remarks: Although the original description of S. temuispiculatum (THOMson and 
DEAN, 1931), on which to base a judgment as to the identification, is far from satisfactory, the present specimen seems to me referable to it, especially in spiculation. The differences, if any, may be due to the size of the colony.

Distribution: Djampeah (Flores Sea, East Indies).

\section{Sarcophyton trocheliophorum MARENZELLER}

Material examined: One specimen, $7 \mathrm{~cm}$ high, Koror, Palau Islands, 1937, coll. T. Yamanouchi (S. M. B. L.).

Distribution: Widespread in the Indo-Westpacific, as far north as Tokara Islands, southern Japan.

\section{Lobophytum crebriplicatum MARENZELLER}

Material examined: One specimen, $7.5 \mathrm{~cm}$ high, koror, Palau Islands, March 1915, coll. S. TAKAHASHI (Z. I. K.)

One specimen, Turihama at Titizima, Bonin Islands, March 1894, coll. S. Hirota and R. SEKIGUCHI (Z.I. T.).

Distribution: Tonga Islands, Low Isles, Madagascar, southern Japan (Tokara Islands).

\section{Family Nephtheidae (VERRILL) emend. UtinOmi}

\section{Capnella fungiformis KüKENTHAL}

(Fig. 5)

Capnella fungiformis KüKenthal, 1903, p. 133, pl. 7, fig. 5; pl. 9, figs. 30-32; Thomson and Mackinnon, 1910, p. 179, pl. 5, fig. 11; THOMSON and DeAn, 1931, p. 71, pl. 10, figs. 2 and 5; MACFADYEN, 1936, p. 48.

Material examined: 3 specimens, 4-6 cm high, Palau Islands, March 1915, coll. S. TAKAHASHI (Z. I. K.).

Three brownish-gray colonies, the largest one of which has a height of $6 \mathrm{~cm}$ and a basal diameter of $4 \mathrm{~cm}$, have a fungiform appearance characteristic to this species. Polyp-bearing lobes are $7-10 \mathrm{~mm}$ long and $5-6 \mathrm{~mm}$ in diameter, each covering densely incurved polyps about $1.8-2.2 \mathrm{~mm}$ long and $0.8-1.5 \mathrm{~mm}$ wide. The polyp armature consists of warty spindles $(0.12 \times 0.035 \mathrm{~mm} \sim 0.4 \times 0.15 \mathrm{~mm})$ which may be clavate owing to slight foliation at the thickened end. The sterile stalk shows heavily warted capstans, $0.05 \times 0.017 \mathrm{~mm} \sim 0.2 \times 0.07 \mathrm{~mm}$ and in the interior includes the typical jagged double-spheres $(0.12 \times 0.08 \mathrm{~mm})$ or barrel-shaped spicules $(0.2 \times 0.15 \mathrm{~mm})$, with sometimes no hint of median waist.

Distribution: Indian Ocean (Coetivy and Dar es Salaam), Great Barrier Reef (Low Isles), East Indies. 

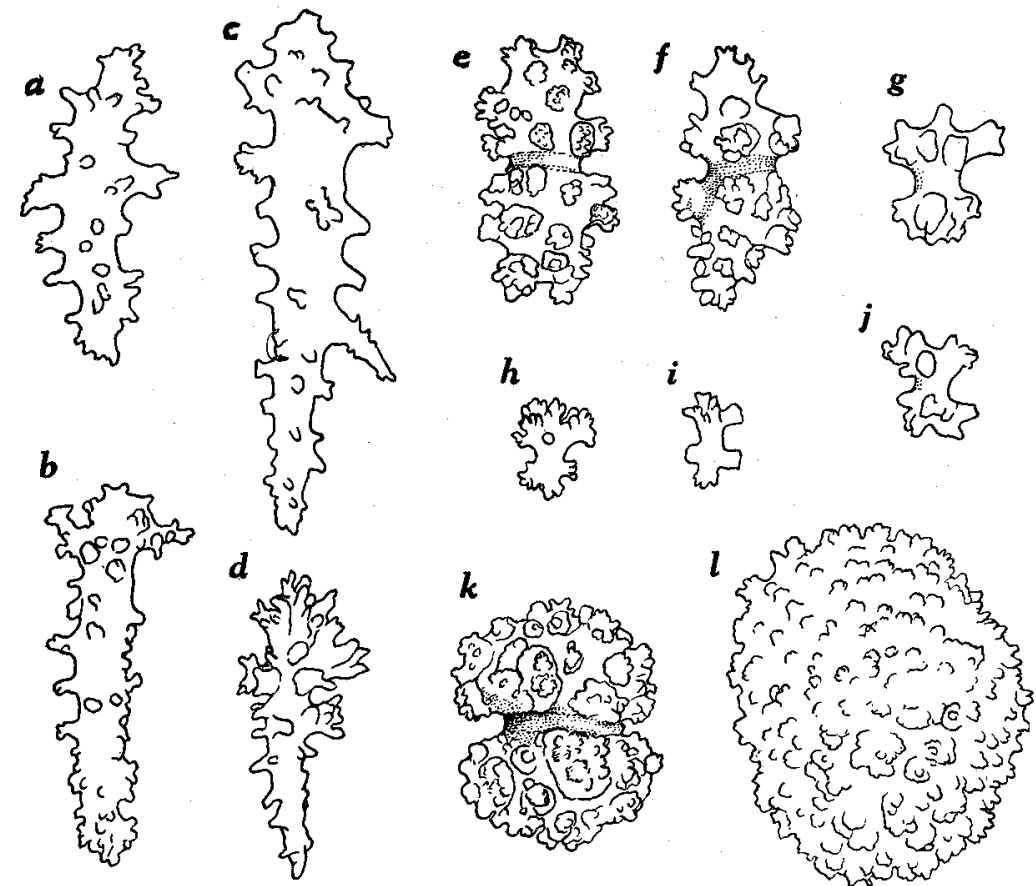

Fig. 5. Capnella fungiformis KüKENTHAL.

Spicules: $a-d$, polyps; $e-j$, stalk cortex $; k-l$, stalk interior. (All $\times 150)$

\section{Paralemnalia thyrsoides (EHRENBERG)}

(Fig. 6)

Ammothea thyrsoides KLUnzINGER, 1877, p. 31, pl. 2, fig. 3; MAY, 1900, p. 134, pl. 2, fig. 14 (var. ramosa).

Lithophytum thyrsoides ThOMSON and Henderson, 1906, p. 427 (with var. durum).

Lemnalia thyrsoides THOMSON and DEAN, 1931, p. 76, pl. 9, figs. 2 \& 6 .

Paralemnalia thyrsoides KüKENTHAL, 1913, p. 16; RoXAs, 1933b, p. 394, pl. 2, fig. 1; pl. 4, fig. 9 ; MACFADYEN, 1936, p. 55.

Material examined: One specimen. Ngarengelngael Passage in Iwayama Bay, Koror Island, 1934, coll. H. UTinomi (S. M. B. L.).

The colony of this peculiar species, brownish in life, is very abundant on the sandy flat in the southern entrance of Iwayama Bay, Koror Island. The polyps are uniformly distributed all over the finger-like lobes, up to $7 \mathrm{~cm}$ long in the extended condition, arising from the membranous base. They are about $1 \mathrm{~mm}$ apart at the tip, more widely apart downwards and expand fully under the water. In the preserved material, the polyps are entirely retracted and the lobes are very brittle because of the spongy texture of the coenenchyme. 
Distribution: Red Sea, Indian Ocean (Tumbatu, Zanzibar), East Indies, Great Barrier Reef (Yonge Reef), Philippines and southernmost cape of Formosa.

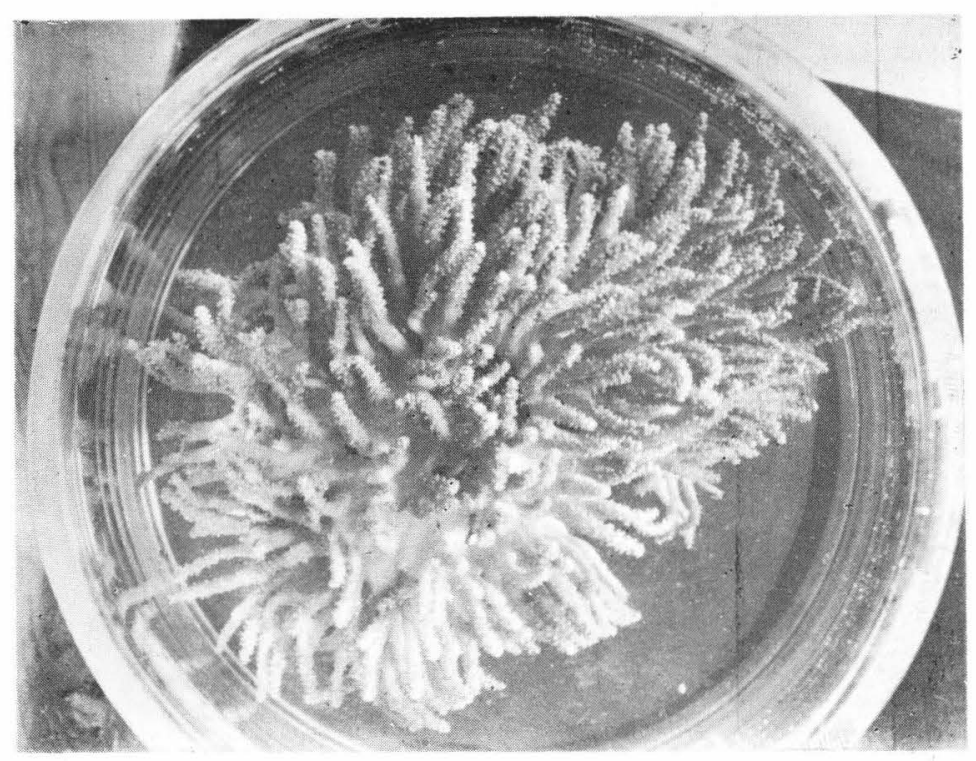

Fig. 6. Paralemnalia thyrsoides (EHRENBERG).

A living colony (photo by H. Utinomi at Palau). ( $\times 1 / 4)$

\section{Nephthea chabrolii Audouin}

Nephthea chabrolii Utinomi, 1954b, p. 59, fig. 2 (with synonymy).

Material examined: One specimen, $6 \mathrm{~cm}$ long, Palau Islands, March 1915, coll. S. TAKAHASHI (Z.I.K.).

The general appearance and spiculation agree well with my former description of this species from Kii coast, middle Japan, excepting that the coenenchymal spicules of the stalk attain up to $3 \mathrm{~mm}$ long and $0.3 \mathrm{~mm}$ wide.

Distribution: Widespread in the Indo-Westpacific, as far north as middle Japan (Kii coast).

\section{Dendronephthya köllikeri KüKENTHAL}

(Fig. 7)

Dendronephthya köllikeri KükENTHAL, 1905, p. 573, text-fig. J, pl. 27, fig. 15.

Material examined: One specimen, $11 \mathrm{~cm}$ long, Palau Islands, March 1915, coll. S. TAKahashi (Z. I. K.). 
One specimen, $5 \mathrm{~cm}$ long, Palau Islands, collector and date unknown (Z. I.T.)

A large glomerate colony collected by $\mathrm{S}$. TAKAHASHI consists of two main branches, about $7 \mathrm{~cm}$ long and a sterile stalk, about $4 \mathrm{~cm}$ long, which are generally flattened in one plane with a maximum width of $6.5 \mathrm{~cm}$. Basal branches are numerous and foliaceous, encircling the top of the stalk.

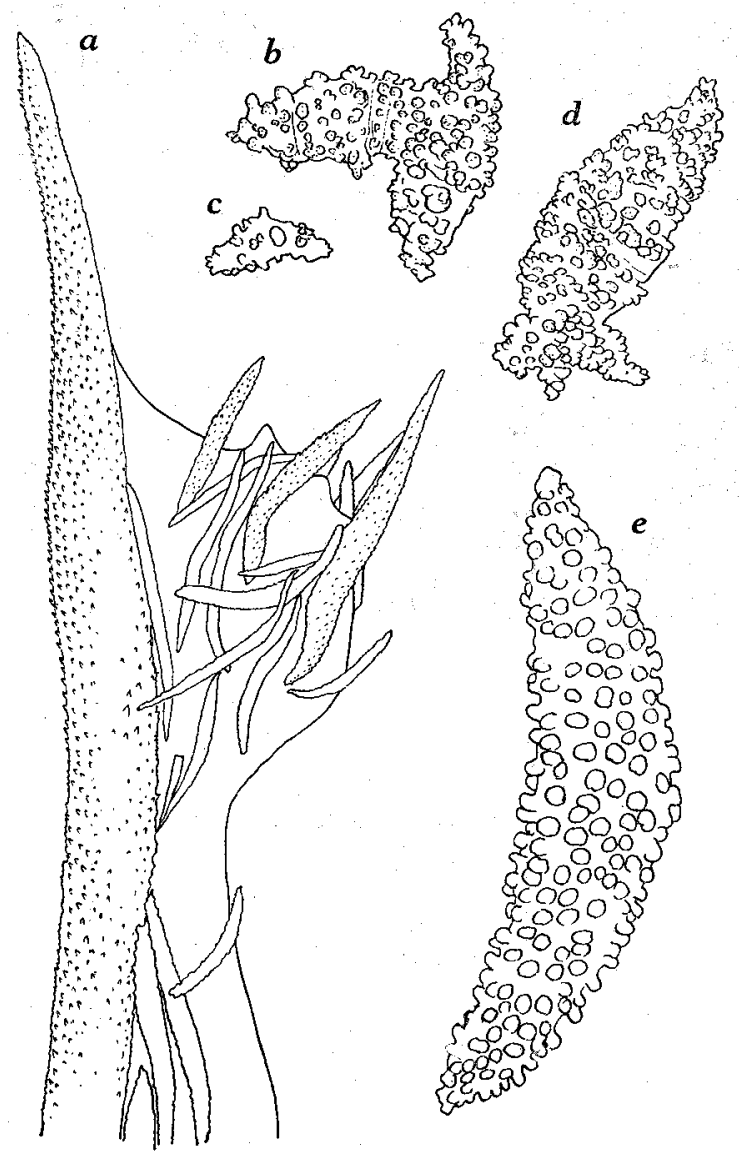

Fig. 7. Dendronephthya köllikeri KÜKENTHAL.

$a$, polyp; $b-d$, spicules of stalk cortex; $e$, spicule of canal-walls.

Cortex of stalk and branches is thickly arranged transversely with remarkable white spicules up to $5 \mathrm{~mm}$ long. Downwards they become somewhat irregular in arrangement and contain triradiate or irregular-shaped smaller spicules, about 0.35 $\times 0.17 \mathrm{~mm} \sim 2.5 \times 0.3 \mathrm{~mm}$. Canal-walls are filled with $2 \mathrm{~mm}$ long and $0.3 \mathrm{~mm}$ wide plump spindles with flattened large warts scattered all over.

Polyps are compactly grouped and remarkable in very strongly projecting 
supporting-bundle spicules of which the longest one is up to $5 \mathrm{~mm}$ long. Point spicules are distantly arranged in eight rows, each in 2 or 3 pairs; uppermost one is hockey-club-shaped, up to $1 \mathrm{~mm}$ long and highly projects for about $0.3 \mathrm{~mm}$ long beyond polyp-head. Dorsal and ventral rows are occasionally unpaired. Thus the formula of anthocodial armature follows:

$$
\mathrm{IV}=1 \mathrm{P}+(1-2) \mathrm{p}+0 \mathrm{Cr}+\text { very strong } \mathrm{S} . \mathrm{B} .+0 \mathrm{M}
$$

These anthocodial spicules are brownish or orangish yellow, while the other spicules colorless.

Distribution: This species, originally recorded from the Palaus, is so far unknown elsewhere.

\section{Dendronephthya palaoensis UTINOMI}

Dendronephthya palaoensis UtiNomi, 1952, p. 140, text-fig. 11, pl. 10, fig. 11.

Material examined: One specimen, Koror Island, Palau Islands, 1937, coll. T. YAMANOUCHI (S. M. B. L.).

This species belonging to the divaricate group has been fully described in my former paper given above.

\section{Dendronephthya spinulosa (GRAY)}

Dendronephthya spinulosa Uтімomi, 1952, p. 191, text-fig. 18, pl. 10, fig. 14

Material examined: One specimen, Palau Islands, March 1915, coll. S. TAKAHASHI (Z.I. K.).

The specimen here examined from Palau is gigantic, probably of the greatest size in this group, next to $D$. maxima KüKenTHAL $(78 \mathrm{~cm}$ long) from Sagami Bay. Namely it is about $60 \mathrm{~cm}$ in total length of which $42 \mathrm{~cm}$ belongs to the sterile stalk. The stalk is gradually tapering upwards, the diameter being about $11 \mathrm{~cm}$ at the base and only $2 \mathrm{~cm}$ at the top. The polyparium is formed of three main branches, measuring respectively $9 \mathrm{~cm}, 12 \mathrm{~cm}$ and $18 \mathrm{~cm}$ in length. In addition, there are two foliaceous branchlets at the base of polyparium.

The spiculation exactly agrees with that of the Japanese specimen, though the anthocodial armature is not so brittle as previously noted.

All polyp spicules are orangish, the upper branches white, while the stalk brownish red.

Distribution: Indian Ocean, China Sea, middle Japan (Tanabe Bay). 


\section{COENOTHECALIA}

\section{Family Helioporidae MoselEy}

\section{Heliopora coerulea (PALLAS)}

Heliopora coerulea EGUCHI, 1938, p. 387 ; EGUCHI, 1948, p. 362 , pl. 60, figs. 3,4 \& 6; UTINOMI, 1953, p. 159.

Material examined: Several dry specimens, outer reef of Palau Islands, 1934, coll. H. UTinomi (S. M. B. L.).

As was noted in my paper on the cirripeds of the Palau Islands, the blue coral occurring commonly in the Palau Barrier Reef is sometimes infested with a peculiar barnacle, Tetraclita (Tesseropora) wiréni Nilsson-CANTEll (HIRo, 1937a, p. 68, p1. 3, fig. 4). Its occurrence in the coral is only detectable by a circular pore on the surface of the coral. According to EGUCHI (1948), frequently this is also perforated by commensal or parasitic worms (probably a kind of polychaetes).

Distribution: Widespread in the Indo-Westpacific, as far north as Ryâkyû Islands.

\section{GORGONACEA}

\section{Family Melithaeidae (GRAY) emend. RIDLEY \\ (=Melitodidae WRIGHT et STUDER) \\ Melithaea* ochracea (LinNAEUS)}

(Fig. 8, $a-k$ )

Melitodes ochracea Kükenthal, 1911, p. 334, text-figs. 54-60, pl. 23, fig. 20; Nutting, 1911, p. 38; HiCrson, 1932, p. 469; HiCrson, 1937, p. 97, figs. 5-7; STiAsny, 1940, p. 218, text-fig. E, pl. 9, figs. 12-13; pl. 14, figs. 34-35.

Material examined : 2 dry specimens, Palau Islands, 1937, coll. T. YAMANOUCHI (S. M. B. L.).

Two colonies of this well-known species, $28 \mathrm{~cm}$ and $22 \mathrm{~cm}$ long respectively, are both irregularly fan-shaped in growth and scarcely reticulate around the main stems. The main stems are somewhat flattened measuring as $10 \times 13 \mathrm{~mm}$ to $11 \times 14 \mathrm{~mm}$ in

* Since the emendation by VerRill (1864), the name Melitodes has long been used for the genus as a substitute name for Melitea or Melitaea. However, the other older name Melithaea, which has been used by H. Milne-Edwards (1857), KöLliKER (1865) and GrAy (1870), but not by later workers, is not to be treated as a homonym of such names according to the latest Copenhagen Decision on Nomenclature (1953). There is no decisive evidence to prove whether it is a substitute name for Melitaea or the result of only an inadvertent error in spelling, but the new genus name Melitodes was not accepted by GrAY (1870), merely quoting a suggestion of VERRILL without comment. For the above reasons it seems better to retain the name Melithaea for the genus instead of Melitodes. 
diameter and the branches run almost parallel to the main stems. The nodes are distinctly hollowed on outer surface and separated on an average by a length of $15 \mathrm{~mm}$ $(13-20 \mathrm{~mm})$. The polyps are usually distributed on one side of the flabellum and they are mostly small, about $0.45 \mathrm{~mm}$ in diameter.

The anthocodial armature, as illustrated by HICKson and STIASNY, consists of eight chevroned rows of curved spindles, about 4 pairs in each point, arranged above

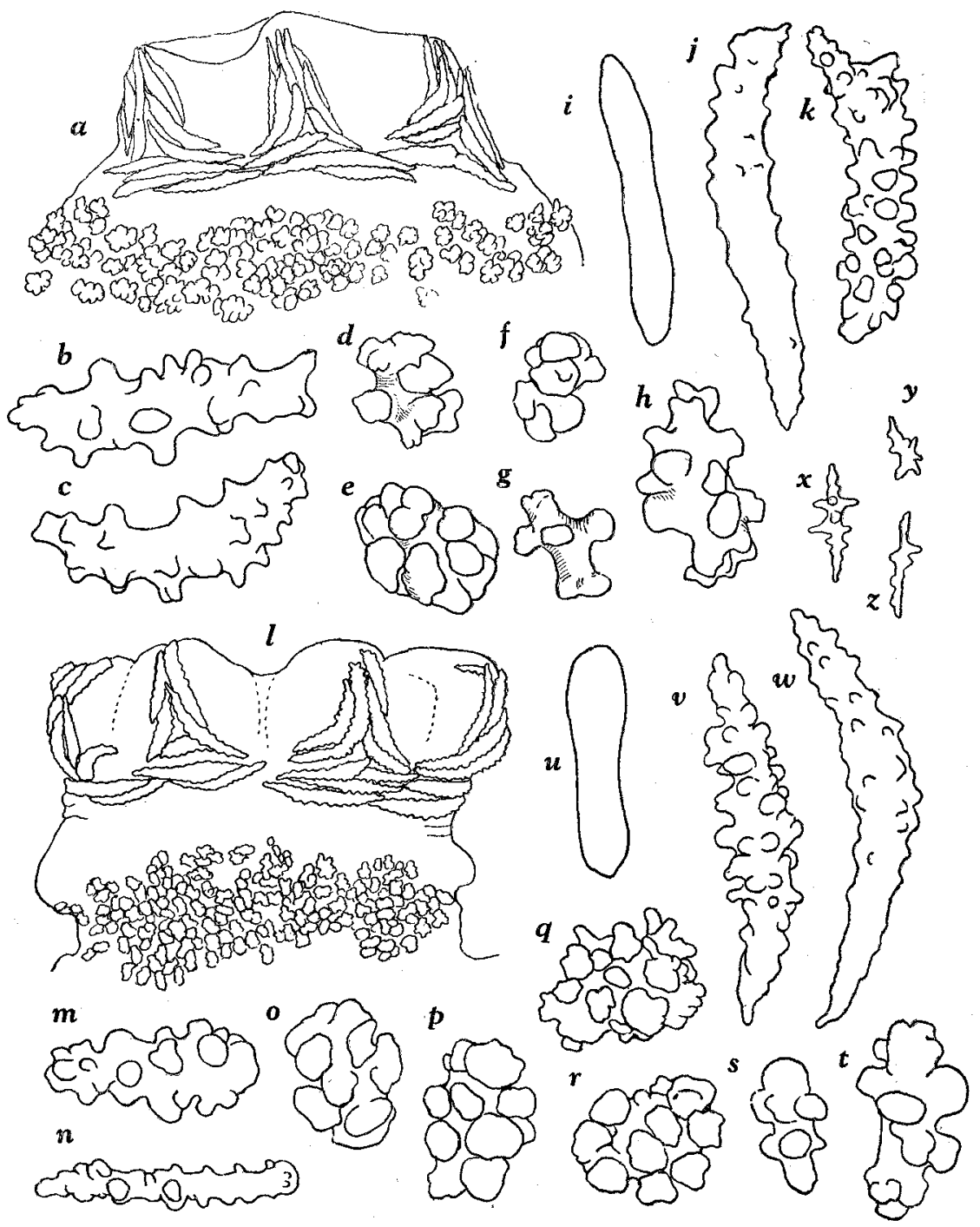

Fig. 8. $a-k$, Melithaea ochracea (LINNAEUS): $a$, polyp; $b-h$, coenenchymal spicules; $i$, spicule of node; $j-k$, point spicules. $l-z$, Melithaea squamata (NuTtinG) $: l$, polyp; $m$ - $t$, coenenchymal spicules; $u$, spicule of node; $v-w$, point spicules; $x-z$, tentacle spicules. ( $a$ and $l, \times 80$; the rest, $\times 335$ ) 
a collaret ring composed of two straight spindles transversely placed; they measure $0.088 \times 0.017 \mathrm{~mm} \sim 0.16 \times 0.07 \mathrm{~mm}$. The coenenchyme is filled with spindles, clubs and their deformed oval forms with large blunt tubercles, $0.035 \times 0.03 \mathrm{~mm} \sim 0.1 \times 0.05 \mathrm{~mm}$. The node includes smooth rodlets, about $0.08-0.1 \mathrm{~mm}$ long.

The color of the entire colony is red, but the spicules are orange or colorless in the coenenchyme and yellow in the anthocodiae.

Distribution: Indian Ocean, East Indies, Great Barrier Reef.

\section{Melithaea squamata (NuTTING)}

(Fig. 8, $l-z$ )

Melitodes squamata Nutring, 1911, p. 41, pl. 7, fig. 1; pl. 12, fig. 1 ; HiCKson, 1937, p. 120. M. squamosa KüKenthal, 1919, p. 150; KÜKENTHAL, 1924, p. 62 (erroneous spelling of squamata).

Material examined: One colony broken into fragments, Palau Islands, March 1915, coll. S. Takahashi (Z. I. K.).

The specimen, though incomplete, is undoubtedly fabellate and not reticulate in growth, as in the original description of this species. The main stem is round in cross section, about $12 \mathrm{~mm}$ in diameter, but the branchlets are somewhat compressed. All the branches are borne on the horny nodes where are much swollen. Polyps are distributed on three sides, leaving the back of the flabellum bare, but as a rule they are arranged in two lateral rows on branches, with a few scattered between them on a median upper surface of the stem. The verrucae are remarkably small for the size of the colony, the usual diameter being only $0.5 \mathrm{~mm}$. They are crimson red in conflict with the yellow color of the coenenchyme of the colony. The nodes and internodes of the axis have the same color as the verrucae, though the tentacles are pale yellow to colorless.

The spicules are almost alike those of the preceding species, although the anthocodial spicules of the points $(0.12-0.25 \mathrm{~mm}$ long) are fewer in number. The coenenchyme is filled with very small, yellow spicules, mostly tuberculated spheres (usually $0.05 \times 0.04 \mathrm{~mm}$ ). In the verrucae, the tuberculated spicules are more or less larger, including ovals or club-like forms $(0.035 \times 0.017 \mathrm{~mm} \sim 0.09 \times 0.035 \mathrm{~mm})$. The nodes are thickly filled with smooth rodlets of orangish color, about $0.035-0.085 \mathrm{~mm}$ long.

Distribution: East Indies (off Timor), $34 \mathrm{~m}$ (type locality).

\section{Family Isididae StUdeR}

\section{Isis hippuris LINNAEUS}

Isis hippuris SIMPSON, 1906, p. 421, pl. 43; KÜKENTHAI, 1924, p. 443; HICKSON, 1932, p. 470 ; HICKSON, 1938, p. 596. 
Material examined: 3 bleached fragments, $13 \mathrm{~cm}, 16 \mathrm{~cm}$ and $18 \mathrm{~cm}$ in length, Helen Reef, southernmost of Palau Islands, 1937, coll. T. Yamanouchi (S. M. B. L.).

This well-known species is represented in the collection by three imperfect specimens, lacking all the coenenchyme and attachment bases. It is easily identified, however, by the white calcareous internodes furrowed longitudinally and the brown horny nodes markedly constricted, alternating one another. The maximum diameter of the axis is about $5 \mathrm{~mm}$ where about 20 low ridges encircle.

Distribution: Indo-Westpacific in shallow seas.

\section{Family Plexauridae GRAY \\ Plexaura flava NutTing}

(Fig. 9, $a-i$ )

Plexaura flava Nutting, 1910, p. 8, pl. 2, fig. 1; pl. 4, fig. 6; StiasnY, 1935, p. 55, text-fig. P, pl. 4, fig. 21; StLasny, 1940, p. 239.

Euplexaura flava KüKEnTHAL, 1924, p. 100.

Material examined: A single specimen, $22 \mathrm{~cm}$ long, Palau Islands, March 1915, coll. S. TAKAHASHi (Z. I. K.).

The specimen agrees well with NUtTrNG's description and figures of this species. The colony in alcohol is light Naples yellow in color, with the brown axis. The branchlets are given off in a pinnate arrangement from the main stem and primary branches, at intervals of $3-7 \mathrm{~mm}$ and at an angle of about $60^{\circ}-70^{\circ}$ to the axis. The calyces, about $0.4 \mathrm{~mm}$ in diameter, are very low and evenly distributed on all sides of the branches. Spicules of the coenenchyme are coarsely warted spindles, sometimes pointed at one end, about $0.1 \times 0.035 \mathrm{~mm} \sim 0.32 \times 0.05 \mathrm{~mm}$. Anthocodial spicules are only smooth rodlets, $0.09 \times 0.0012 \mathrm{~mm}$.

Distribution: East Indies, Sulu Archipelago.

\section{Family Gorgonellidae STUDER}

\section{Junceella squamata TOEPLITZ}

(Fig. 9, $j-q$ )

Junceella squamata ToEPLITZ, 1929, p. 257, text-fig. 1, p1. 6, fig. 1; STIASNY, 1940, p. 246.

Material examined: 5 dry specimens, $49-64 \mathrm{~cm}$ long, Lebugol Channel, Koror Island, Palau Islands, 1937, coll. T. YamanouchI (S. M. B. L.).

The colonies are unbranched, whip-like and dirty white in the dried condition, though two of them are fused together at base. The diameter of the stem does not differ much throughout; in one specimen, for example, it is $7 \mathrm{~mm}$ at base while $4.5 \mathrm{~mm}$ at the terminal end. The proximal part, about $2-4 \mathrm{~cm}$ in length, is usually sterile, 
but with a slight median longitudinal furrow, suggesting a biradial arrangement of polyps. The coenenchyme is comparatively thick and filled with asymmetrical doubleclubs whose heads have smooth warts, about $0.075 \times 0.047 \mathrm{~mm} \sim 0.083 \times 0.047 \mathrm{~mm}$. The verrucal spicules are narrower and more asymmetrical in form than those of the coenenchyme, about $0.07 \times 0.018 \mathrm{~mm} \sim 0.084 \times 0.028 \mathrm{~mm}$.

Distribution: Philippines, Formosa, East Indies.

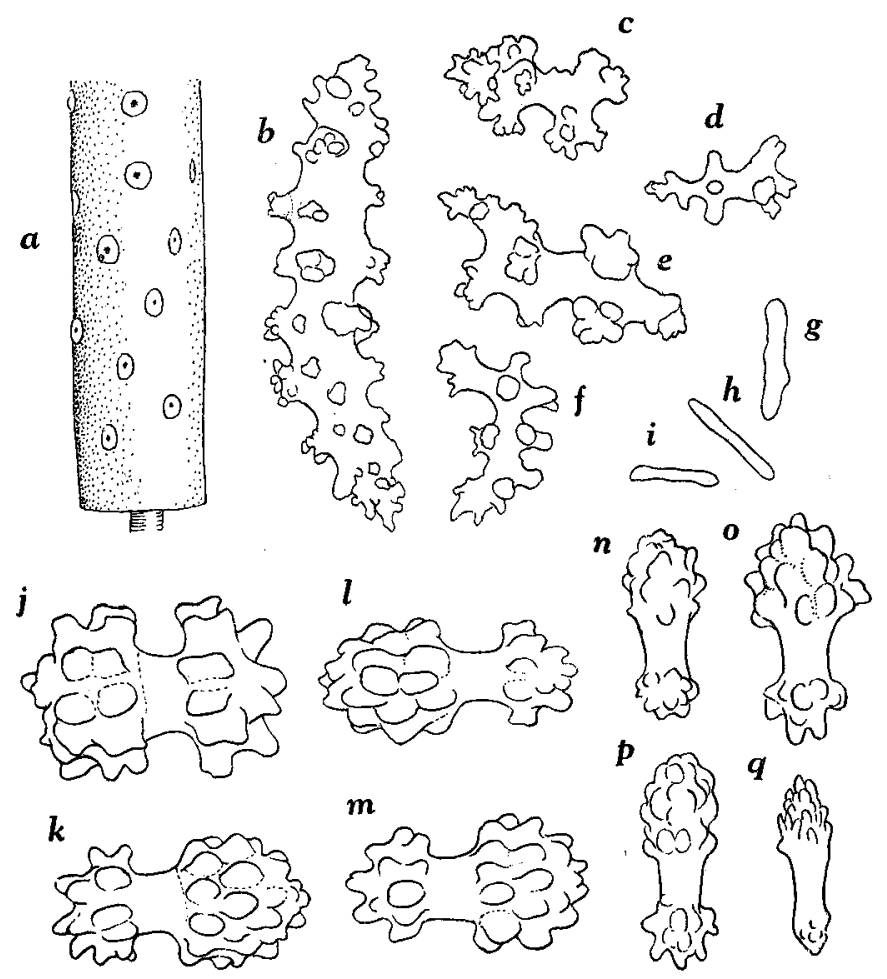

Fig. 9. $a-i$, Plexaura flava NutTING: $a$, part of branchlet; $b-f$, coenenchymal spicules of main stem; $g-i$, polyp spicules. $j-q$, Junceella squamata Toeplitz: $j-m$, stem spicules; $n-q$, verrucal spicules. $\quad(a, \times 5 ; b i, \times 150 ; j-q, \times 335)$

\section{PENNATULACEA}

\section{Family Pennatulidae KöLLIKER}

\section{Pennatula fimbriata HeRKLOTs}

Material examined: 2 specimens, both $23 \mathrm{~cm}$ long, Ngarengelngael Passage, Koror Island, 1937, coll. T. Yamanouchi (S. M. B. L.).

Distribution: Japanese and Malayan Seas. 


\section{LITERATURE}

Eguchr, M. 1938. A systematic study of the reef-building corals of the Palao Islands. Palao Trop. Biol. Sta. Studies, 1 (3) : 325-390.

1948. Fossil Helioporidae from Japan and the South Sea Islands. Journ. Paleont., 22 (3) : 362-364, pl. 60 .

Gohar, H. A. F. 1940. A revision of some genera of the Stolonifera. Publ. Mar. Biol. Sta. Ghardaqa (Red Sea), $3: 1-23,1$ pl.

GraY, J. E. 1870. Catalogue of Lithophytes or stony corals in the collection of the British Museum. 51 pp. London.

GressitT, J. L. 1954. Insects of Micronesia. Introduction. Insects of Micronesia, 1: ix +257 pp.

Hickson, S. J. 1919. Sur quelques specimens d'un Alcyonium d'Annam Alcyonium krempfi n. sp. Bull. Soc. Zool. France, 44: 411-424.

1921. On some Alcyonaria in the Cambridge Museum. Proc. Cambridge Phil. Soc., 20 (3) : 366-373.

1932. Gorgonacea. Great Barr. Reef Exped., Sci. Rep., 4 (13) : 459-512.

1937. The family Melitodidae. Trans. Zool. Soc. London, 23 (3): 73-209, pl. 14.

1938. The Gorgonacea from Torres Straits collected by Prof. A. C. Haddon,

F.R.S., 1888-1889, with notes on the genera Hicksonella and Pseudothesea. Proc. Zool. Soc.

London, 108 (3) : 585610.

Hiro, F. 1937a. Cirripeds of the Palao Islands. Palao Trop. Biol. Sta. Studies, 1 (1): 37-72, pl. 3.

1937b. Observations on the alcyonarian Heteroxenia elizabethae Kölliker. Annot. Zool. Japon., 16 (3) : 237-244.

KLunZINGER, C. B. 1877. Korallthiere des Rothen Meeres. Erster Theil : Die Alcyonarien und Malacodermen. vii +94 pp., 7 pls. Berlin.

Kükenthal, W. 1903. Versuch einer Revision der Alcyonarien. II. Die Familie der Nephthyiden. 1 Theil. Zool. Jahrb. Abt. Syst., 19 (1) : 99-172, pls. 7-9. 1905. Versuch einer Revision der Alcyonarien. II. Die Familie der Nephthyiden. 2 Teil. Die Gattungen Dendronephthya n. g. und Stereonephthya n. g. Ibid., 21 (5/6): 503-726, pls. $26-32$.

1911. Alcyonarien von den Aru- und Kei-Inseln nach den Sammlungen von Dr. H. Merton. Abh. Senckenb. naturf. Ges. Frankfurt, 33 (4) : 305-346, pls. 19-23.

pls. $30-89$. 1919. Gorgonaria. Wiss. Ergeb. der Deut. Tiefsee-Exped., 13 (2): 1-948, 1924. Gorgonaria. Das Tierreich, 47 Lieferung, xxviii+478 pp. Berlin $u$. Leipzig.

LAACKMANN, H. 1909. Zur Kenntnis der Alcyonarien-Gattung Telesto Lmx. Zool. Jahrb. Suppl. 11 (1): 41-104, pls. 2-8.

Macfadyen, L. M. I. 1936. Alcyonaria (Stolonifera, Alcyonacea, Telestacea and Gorgonacea). Great Barr. Reef Exped., Sci. Rep., 5 (2) : 19-71, pls. 1-3.

MAY, W. 1900. Beiträge zur Systematik und Chorologie der Alcyonaceen. Jena. Z. Naturw., $33: 1-180$, pls. $1-5$.

Molander, A. R. 1929. Die Octactiniarien. Further Zool. Res. Swedish Antarctic Exped., 2 (2) : 1-86, pls. $1-4$.

NutTing, C. C. 1910 . The Gorgonacea of the Siboga Expedition, IV. The Plexauridae. SibogaExped., Monog. 13b1, Livr. 48. 20 pp., 4 pls. Leiden.

Monog. $13 \mathrm{~b}^{5}$, Livr. 57.62 pp., 12 pls. Leiden.

Roule, L. 1908. Alcyonaires d'Amboine. Rev. Suisse Zool., 16 (2) : 161-194, pls. 6-8.

Roxas, H. A. 1933a. Philippine Alcyonaria. The families Cornulariidae and Xeniidae. Philip. Journ. Sci., 50 (1) : 49-110, pls. 1-4. 
Roxas, H. A. 1933b. Philippine Alcyonaria, II. The families Alcyoniidae and Nephthyidae. Ibid., 50 (4) : 345-470, pls. $1-5$.

Simpson, J. J. 1906. The structure of Isis hippuris, Linnaeus. Journ Linn. Soc. London, Zool., $37: 421-433$, pl. 43.

Stiasny, G. 1935. The Gorgonacea der Siboga-Expedition. Supplement I. Revision der Plexauridae. Siboga-Exped., Monog. 13b7, Livr. 124, vi +106 pp., 7 pls. Leiden.

1940. Biological results of Snellius Expedition, VII. Die Gorgonarien-Sammlung der Snellius-Expedition. Temminckia, 5: 191-256, pls. 6-14.

Thomson, J. A. and DeAn, L. M. I. 1931. The Alcyonacea of the Siboga Expedition, with an appendam to the Gorgonacea. Siboga-Exped., Monog. 13d, Livr. 115. 227 pp., 28 pls. Leiden. and Henderson, W. D. 1906. The marine fauna of Zanzibar and British East Africa from collections made by Cyvil Crossland in the years 1901-1902.-Alcyonaria. Proc. Zool. Soc. London, 1906 (1) : 393-443, pls. 26-31.

and Mackinnon, D. L. 1910. Alcyonarians collected on the Percy Sladen Trust Expedition by Mr. J. Stanley Gardiner, M.A., F.R.S. Part 2. The Stolonifera, Alcyonacea, Pseudoxonia and Stelechotokea. Trans. Linn. Soc. London, Ser. 2, 13 (Zool.) : 165-211, pls. 6-14.

Tixier-Durivault, A. 1948. Révision de la famille des Alcyoniidae. Genre Lobularia. Mém. Mus. Nation. d'Hist. Nat,, N. S., 23 (1) : 1-256.

Toeplitz, Ch. M. 1929. Die Gorgonarien Westindiens. Kap. 7, Die Familie Gorgonellidae, zugleich eine Revision. Zool. Jahrb., Suppl., 16 (2) : 235-376, pls. 6-7.

Utinomi, H. 1950. Some xeniid Alcyonarians from Japan and adjacent localities. Publ. Seto Mar. Biol. Lab., 1 (3) : 81-91.

1952. Dendronephthya of Japan, I. Dendronephthya collected chiefly along the coast of Kii Peninsula. Ibid., 2 (2) : 161-212, pls. 9-11.

1953. Invertebrate fauna of the intertidal zone of the Tokara Islands. VI. Alcyonaria. Ibid., 3 (2): 149-160, pl. 8.

1954a. Some Alcyoniid octocorals from Kii coast, middle Japan. Ibid., 4 (1): 43-55, pl. 1.

1954b. Some Nephtheid octocorals from Kii coast, middle Japan. Ibid., 4(1): 57-66, pl. 2.

VERRILL, A. E. 1864. List of the polyps and corals sent by the Museum of Comparative Zoölogy to other institutions in exchange, with annotations. Bull. Mus. Comp. Zoöl. Harvard Coll., $1: 29-60$.

Wright, E. P. and Studer, Th. 1889. Report on the Alcyonaria collected by H.M.S. Challenger during the years 1873-76. Challenger Report, Zoology, 31 (64): lxxii +314 pp., 43 pls. London. 